\title{
APLIKASI TOPIC MODELING PADA PEMBERITAAN PORTAL BERITA ONLINE SELAMA MASA PSBB PERTAMA
}

\author{
Wahyudin ${ }^{1}$ \\ ${ }^{1}$ Politeknik Statistika STIS \\ Email:wahyudin@stis.ac.id
}

\begin{abstract}
ABSTRAK
Salah satu respon pemerintah dalam menanggapi semakin meningkatnya penyebaran pandemi Covid19 dengan mengeluarkan kebijakan Pembatasan Sosial Bersekala Besar (PSBB). Kebijakan ini diberlakukan sejak 10 s.d. 23 April 2020. Tulisan ini mencoba mengungkap pemberitaan beberapa media masa online selama pemberlakuan kebijakan tersebut. Metode analisis dalam tulisan ini mengunakan pendekatan text mining dengan mengaplikasikan teknik LDA dalam topic modeling. Dari 20 jumlah topik yang ditetapkan sebelumnya kemudian dilakukan evaluasi dengan menggunakan nilai koherensi dan prevalensi masingmasing topik tersebut. Selain tiu juga dilakukan pengelompokan topik yang memungkinkan dengan menggunakan teknik dendrogram. Hasil penelitian ini menunjukkan bahwa selama pemberlakuan kebijakan PSBB pemberitaan 9 media online nasional dapat dikelompokkan kedalam 4 kelompok besar pemberitaan: perkembangan kasus Covid-19, penanganan dampak pademi, seputar Ramadhan dan kegiatan belajar di rumah, serta berita lain-lain diantaranya seputar: PSBB, kriminal, hiburan, dan politik.
\end{abstract}

Kata kunci: text mining, topic modeling, LDA, pemberitaan, dendrogram

\begin{abstract}
One of the government's responses in response to the increasing spread of the Covid-19 pandemic is by issuing a Large-Scale Social Restriction (PSBB) policy.The Covid-19 pandemic, which was officially announced by the government since March 2, 2020, has become increasingly widespread. One response to overcoming this condition was the government issued a policy to enforce The Large Scale Social Restrictions (PSBB). This policy was enforced from $10^{\text {th }}$ to $23^{\text {rd }}$ April, 2020. This paper tries to reveal the news on several online media during the implementation of the policy. The method of analysis in this paper uses a text mining approach by applying LDA techniques in topic modeling. Of the 20 previously defined topics, an evaluation was carried out using the coherence and prevalence values of each of these topics. In addition, there is also a possible grouping of topics using the dendrogram technique. The results indicate that during the implementation of the PSBB policy, the news article can be grouped into 4 major news groups: the Covid-19 case update, handling the impact of pandemic, about Ramadan and learning activities at home, and other news about: PSBB, crime, entertainment and politics.
\end{abstract}

Keywords: text mining, topic modeling, LDA, news, dendrogram

\section{PENDAHULUAN}

Saat ini informasi telah menjadi kebutuhan penting dalam kehidupan. Salah satu sumber informasi utama adalah berita, yaitu informasi terkini tentang suatu peristiwa yang terjadi. Sebelum era digital, kebutuhan berita dipenuhi dari berbagai pemberitaan oleh media masa cetak, televisi, maupun radio. Seiring perkembangan teknologi informasi yang demikian pesat, era digital telah memanjakan manusia dengan segala kemudahannya untuk mendapatkan berbagai informasi yang diinginkan. Salah satu kemudahan tersebut adalah dengan munculnya berbagai portal berita online.

Hingga saat ini, media online sangat disukai dan menjadi pilihan bagi sebagian orang untuk memenuhi kebutuhan informasi mereka, setiap saat dan setiap waktu. Hal ini karena media online 
memiliki banyak keunggulan, yaitu: dapat dibaca kapan saja dan dimana saja, dapat dibaca berulang kali sebanyak yang diinginkan, sangat praktis dan selalu update, lebih cepat di peroleh dan dikonsumsi,dan relatif sangat murah. Dewan Pers menyatakan, selama 2016 pertumbuhan media online di Indonesia mencapai sekitar 43 ribu situs. Sekitar 40 ribu media di antaranya belum terverifikasi. "Baru 230 saja terverifikasi di Dewan Pers," tutur Anggota Dewan Pers Ratna Komala saat acara diskusi di Gedung Dewan Pers, Kebon Sirih, Jakarta Pusat, Rabu (26/4/2017). (Nurkinan, 2017).

Tulisan ini mencoba mengungkap pemberitaan oleh portal berita online selama masa PSBB pertama diberlakukan melalui pendekatan text mining. Text mining merupakan metode penemuan pengetahuan atau informasi penting dari sekumpulan data teks melalui identifikasi dan eksplorasi pola yang terkandung di dalam kumpulan teks tersebut (Feldman \& Sanger, 2007). Data teks sebagian besar tidak terstrutur atau paling tidak semi terstruktur, biasanya data tersebut tersimpan dalam dokumen berupa artikel berita, makalah penelitian, buku, perpustakaan digital, email, dan halaman web.

Pendekatan ini dipilih karena perkembangan jumlah portal berita yang luar biasa di era digital juga diiringi pesatnya jumlah produksi berita yang dihasilkan. Sehingga untuk mendapatkan informasi secara global mengenai topik apa saja yang diberitakan oleh portal berita online tidak mungkin dilakukan dengan cara membaca seluruh berita yang ada karena jumlahnya sangat banyak. Salah satu teknik dalam text mining yang berguna dalam membantu memecahkan persoalan tersebut adalah topic modeling.

Selanjutnya dalam tulisan berikut ini dibahas mengenai data dan metodologi yang digunakan, pembahasan hasil yang diperoleh dari aplikasi topic modeling, serta kesimpulan.

\section{DATA DAN METODOLOGI}

Data yang digunakan dalam penelitian ini berupa judul pemberitaan dari 9 portal berita online nasional selama masa pemberlakuan PSBB tahap pertama yaitu dari tanggal 10 s.d. 23 April 2020. Portal berita online nasional yang dimaksud, yaitu: antara.com, republia.com, detik.com, jpnn.com, okezone.com, inilah.com, tempo.com, kompas.com, dan tribun.com. Adapun alasan pemilihan 9 media ini, selain karena sebagian besar media ini termasuk dalam salah satu situssitus berita terpopuler menurut it-jurnal.com yang bersumber dari alexa trafix rank, sebuah situs yang menyediaan informasi tentang ranking atau posisi sebuah situs di internet berdasarkan berbagai faktor ditambah beberapa portal berita yang memungkinkan diperoleh datanya oleh peneliti.

Penerapan metode text mining dalam penelitian ini di lakukan melalui beberapa tahapan seperti gambar1 berikut:

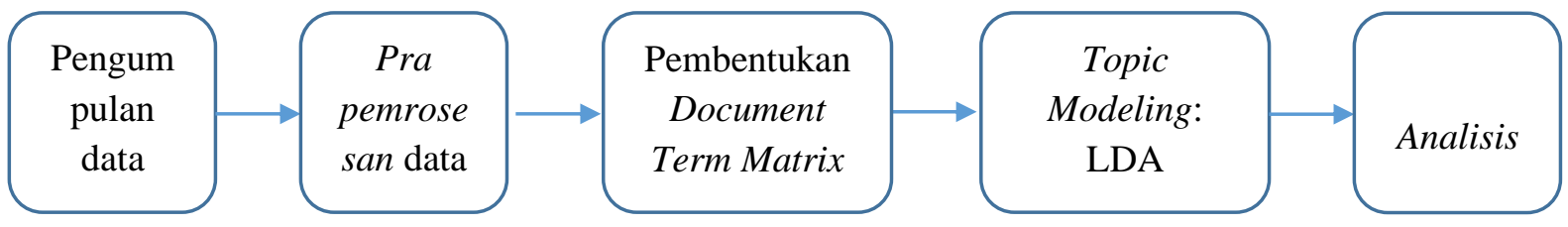

Gambar 1. Tahapan Penelitian.

A. Pengumpulan data 
Data judul pemberitaan dikumpulkan melalui teknik web scrapping menggunakan program $\mathrm{R}$. salah satu batasan penelitian ini adalah hanya menggunakan judul berita sebagai data yang akan dianalisis dan bukan keseluruhan isi pemberitaan, dengan asumsi judul pemberitaan menggambarkan isi berita. Keterbatasan berikutnya adalah tidak semua portal berita online diambil beritanya tetapi hanya 9 portal berita online saja.

B. Pra pemrosesan data

Secara umum tujuan tahapan pra pemrosesan dalam data mining adalah untuk meningkatkan kuaitas data (Han, Kamber, \& Pei, 2012). Tahap pra pemrosesan data merupakan langkah utama dalam text mining dibandingkan dengan data mining karena melibatkan langkahlangkah pemrosesan yang signifikan untuk mengubah teks menjadi format terstruktur yang sesuai untuk analisis selanjutnya (Feldman \& Sanger, 2007)(Feinerer, 2008). Tahapan ini meliputi: Cleansing, Case folding, Tokenizing, Filtering, dan Stemming.

- Cleansing, data dibersihkan dari karakter teks yang tidak diperlukan seperti: tanda baca, angka, tagar, emoji, dsb.

- Case folding, mengubah huruf kapital menjadi huruf kecil.

- Tokenizing, memisahkan setiap kata yang menyusun suatu dokumen. Contoh: "Polisi hingga TNI Dikerahkan Jaga Pusat Perbelanjaan Jakarta Selama PSBB" menjadi: "Polisi", "hingga", "TNI", "Dikerahkan", "Jaga", "Pusat", "Perbelanjaan", Jakarta", "Selama", "PSBB","

- Normalizing, penyesuaian teks dengan bentuk bakunya.

- Filtering, memilih kata-kata yang dianggap mewakili dokumen dari hasil token dengan menghilangkan kata-kata yang dianggap tidak bermakna (stop words) seperti, kata tanya, kata seru, kata hubung, dsb.

- Stemming, mengubah kata berimbuhan menjadi kata dasar (jika diperlikan).

C. Pembentukan Document Term Matrix

Pada tahap ini dibentuk Document Term Matrix (DTM), yaitu suatu matriks yang mencerminkan hubungan antara dokumen dengan kata atau istilah (term). Setiap baris dalam DTM mewakili dokumen dan setiap kolom dalam DTM mewakili term, sementara nilai entrinya adalah jumlah frekuensi kemunculan term dalam dokumen. Selain menggunakan nilai frekuansi kemunculan term dalam dakumen, nilai entri dari matriks DTM dapat juga berupa penimbang lain seperti TF-IDF (Term Frequency-Inverse Document Frequency) dan penimbang biner. Terkadang baris dan kolom dalam matriks DTM ditukar sehingga menjadi matriks TDM (Term Document Matriks). Matriks DTM diperoleh dari Corpus. Corpus adalah kumpulan teks yang tertulis dalam dokumen.

D. Pemodelan Topik atau Topic Modeling

Setelah terbentuk matriks DTM, langkah selanjutnya melakukan pemodelan topik berita atau Topik Modeling (TM). Ada banyak metode dalam TM, menurut (Hofmann, 2001) sebagaimana disebutkan dalam (Alghamdi \& Alfalqi, 2015), diantaranya: Latent Semantic Analysis (LSA), Probabilistic Latent Semantic Analysis (PLSA), Latent Dirichlet Allocation (LDA), Correlated Topic Model (CTM).

Teknik TM yang digunakan dalam tulisan ini adalah LDA yang pertama kali diperkenalkan oleh Blei, Ng dan Jordan pada tahun 2003. LDA mempelajari hubungan antara kata-kata, topik, dan dokumen dengan mengasumsikan dokumen dihasilkan oleh suatu model probabilistik tertentu. 
LDA termasuk model tanpa pengawasan (unsupervised) untuk menemukan topik yang terkandung dalam suatu kumpulan doumen atau teks dengan menggunakan pendekatan statistik (Blei, Ng, \& Jordan, 2003) (Stevens, Kegelmeyer, Andrzejewski, \& Buttler, 2012).

Ide dasar dari proses ini adalah bahwa setiap dokumen $\mathrm{D}$ merupakan campuran topik $\mathrm{k}$ yang bersifat laten, dan setiap topik adalah sebuah distribusi peluang diskrit yang menentukan bagaimana setiap kata muncul dalam suatu topik tertentu. Probabilitas topik ini merupakan representasi ringkas dari sebuah dokumen. Di sini, "dokumen" adalah "sekumpulan kata" tanpa struktur di luar topik dan statistik kata (Alghamdi \& Alfalqi, 2015) (Jelodar et al., 2019).

Sumber: (Alghamdi \& Alfalqi, 2015)

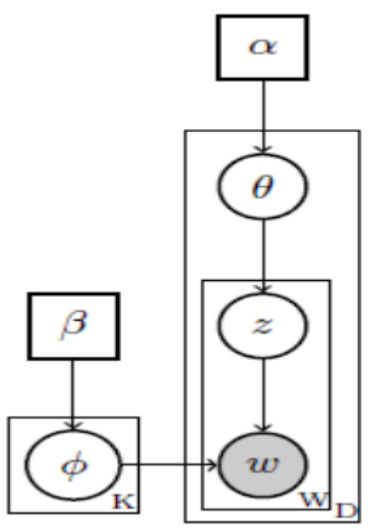

Gambar 2. Gambaran Model LDA Secara Grafis.

Gambar 2 merupakan representasi model grafis dari model LDA. Proses generatif dasar untuk LDA adalah sebagai berikut:

Untuk setiap kata Nj di dalam dokumen j: 1) Pilih topik zij Multinomial ( $\theta j)$; 2) Pilih kata xij Multinomial ( $\varphi z i j)$. Dimana distribusi $\Theta$ mewakili probabilitas setiap topik muncul di setiap dokumen dan distribusi $\varphi$ mewakili probabilitas kata-kata yang digunakan untuk setiap topik (Porteous et al., 2008) (Griffiths \& Steyvers, 2004).

Adapun tahapan pemodelan LDA dalam tulisan ini adalah sebagai berikut:

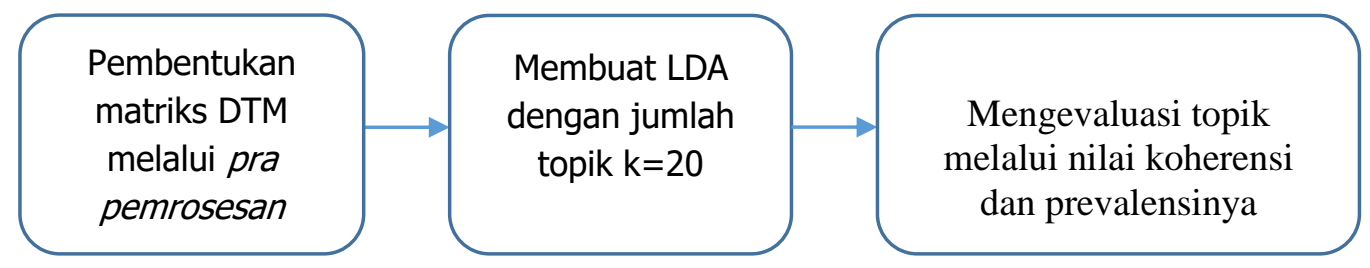

Gambar 3. Tahapan pemodelan LDA.

Setiap topik yang dihasilkan terdiri dari kumpulan kata-kata. Bagaimana cara menarik suatu makna dari kumpulan kata-kata dalam suatu topik tersebut merupakan permasalahan tersendiri dalam analisis topic modeling. Ukuran yang populer digunakan dalam hal ini adalah nilai koherensi (coherence) suatu topik. Nilai koherensi menunjukkan tingkat keterpaduan kata-kata dalam suatu topik yang dihasilkan dari analisis perbedaan/kesamaan semantik antara kata-kata dalam topik tersebut (Stolee, 2016). skor koherensi populer, termasuk skor koherensi yang diusulkan oleh (Mimno, Wallach, Talley, Leenders, \& McCallum, 2011). 
Nilai koherensi membantu membedakan antara topik yang dapat ditafsirkan secara semantik dengan topik yang merupakan hasil temuan inferensi statistik. Dengan kata lain, nilai koherensi memberi informasi tentang kata-kata (terms) dalam sebuah topik. Sedangkan nilai prevalensi (prevalence) memberi informasi mengenai topik yang paling sering muncul dalam korpus. Nilai prevalensi merupakan nilai peluang distribusi topik di seluruh dokumen.

\section{HASIL DAN PEMBAHASAN}

\section{Profil pemberitaan selama PSBB I}

Jumlah pemberitaan yang diproduksi oleh 9 portal berita online selama masa PSBB I sebanyak 59.279 berita dengan rata-rata jumlah produksi berita permedia sebanyak 6.587 berita. Dari jumlah tersebut, Tribun merupakan portal berita online paling produktif menghasilkan berita selama masa PSBB I, yaitu 15.380 berita, kemudian disusul Republika 10.487 berita, dan Antara 7.387 berita. Sedangkan Inilah.com merupakan portal berita online yang paling sedikit memproduksi berita, yaitu hanya 1.108 berita, diatasanya adalah JPNN sebanyak 3.018 berita.

Berdasarkan Gambar 3, produksi berita per hari bersifat fluktuatif. Terlihat bahwa produksi berita mengalami penurunan setiap Sabtu-Minggu dan puncak produksi berita berada pada hari Selasa atau Rabu dengan dominasi pemberitaan dari portal berita Tribun dan Republika.

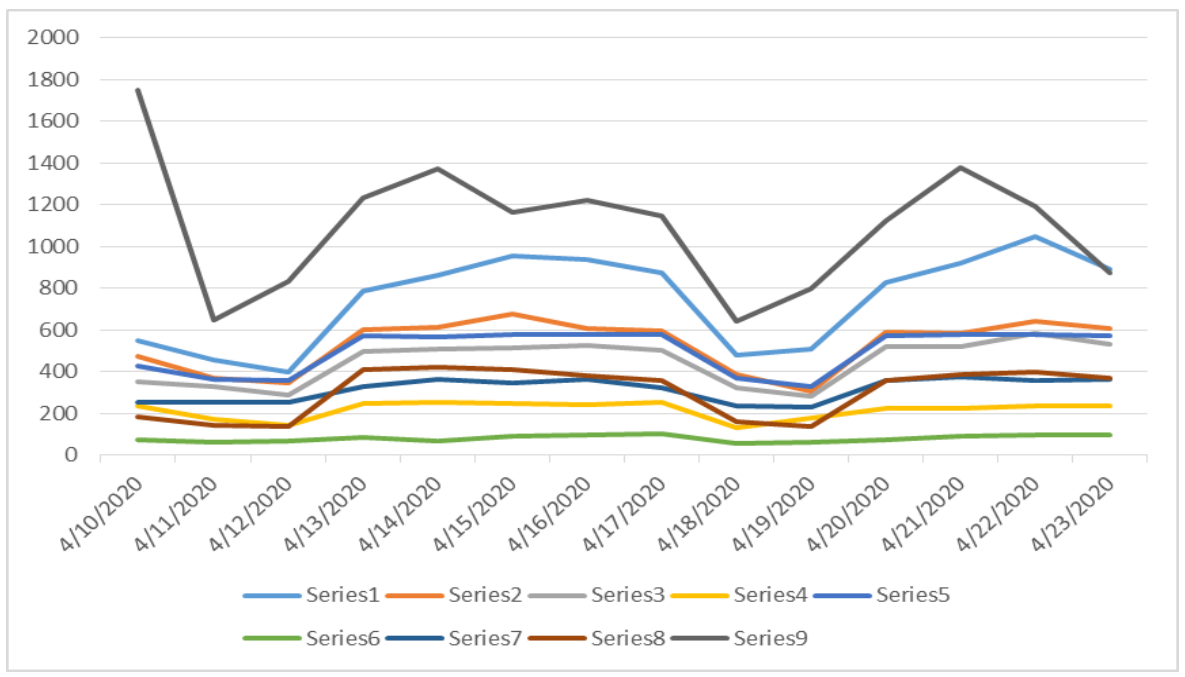

Gambar 3. Jumlah berita per hari selama PSBB I dari 9 media.

Produksi berita oleh portal berita online terus mengalir dalam 24 jam tiada henti. Meski jumlah produksi masih kecil diawal, namun terus meningkat seiring pertambahan waktu. Puncak produksi berita bagi hampir seluruh media yang diamati adalah pada sekitar jam 16-17 setiap harinya, kemudian trennya menurun. 


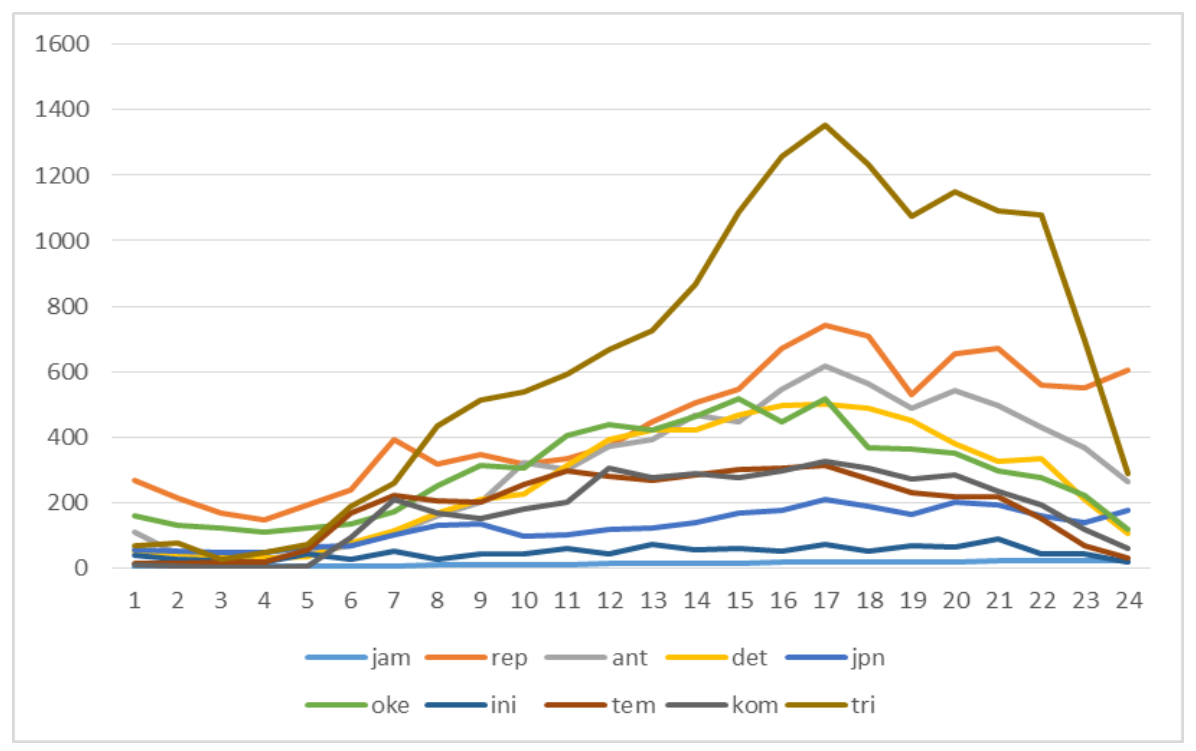

Gambar 4. Jumlah berita per media berdasarkan jam terbit.

Dari sisi penulisan judul artikel, jumlah kata yang digunakan oleh 9 media online tersebut adalah 10 kata, sedangkan jika dilihat dari jumlah hurufnya adalah 66 huruf. Tribun memiliki rata-rata terbanyak dalam jumlah penggunakan huruf yaitu 84 huruf, juga dalam penggunaan kata yaitu 12 kata setiap judul berita. Sedangkan media yang paling irit dalam penggunaan kata dan huruf adalah republika yaitu: 52 rata-rata penggunaan kata dan 8 untuk rata-rata penggunaan hurufnya.

\section{Hasil Topik Modeling menggunakan LDA}

Berdasarkan hasil pemodelan LDA dengan $\mathrm{k}=20$, diperoleh gambaran topik seperti pada Tabel 1 yang memuat 10 kata (term) pada setiap topik terkait. Secara intuisi, maka tema pemberitaan selama PSBB I dari 9 portal berita online adalah:

- Topik1, seputar kebijakan pemerintah pusat terutama mengenai anggaran penanggulangan pandemic dan larangan mudik

- Topik2, seputar kebijakan asimilasi narapidana

- Topik3, seputar bantuan terhadap warga terdampak pandemi

- Topik4, seputar RUU Cipta Kerja

- Topik5, seputar isolasi mandiri pekerja Indonesia di LN

- Topik6, seputar olahraga terutama sepak bola

- Topik7, seputar bantuan untuk tenaga medis dalam menghadapi pandemi

- Topik8, seputar informasi perkembangan warga yang terkena pandemi

- Topik9, seputar protocol kesehatan diantaranya pemakaian masker

- Topik10, seputar wni yang pulang dimasa pandemi

- Topik11, seputar kebijakan belajar di rumah

- Topik12, seputar ramadhan

- Topik13, seputar test Covid-19

- Topik14, seputar dampak pandemic terhadap ekonomi dan dunia industri

- Topik15, seputar meninggalnya seorang artis Glenn Fredly

- Topik16, seputar wabah pandemic Covid-19

- Topik17, seputar dampak PSBB di Jakarta dan sekitarnya, juga terkait angkutan umum

- Topik18, seputar cuaca selama ramadhan dan uji pcr

- Topik19, seputar update perkembangan warga terkena Covid-19 
- Topik20, berita lain-lain

Gambar 5 medeskripsikan nilai koherensi dan prevalensi dari 20 topik yang ditetapkan sebelumnya. Topik-topik yang memiliki koherensi tinggi diantaranya: Topik15, Topik7, Topik13, Topik18, Topik4, dan Topik11. Artinya, topik-topik dengan koherensi yang lebih tinggi nilainya lebih mudah untuk diinterpretasikan berdasarkan kata-kata didalamnya. Misalnya Topik15, sangat mudah untuk menginterpretasikan topik tersebut yaitu seputar pemberitaan artis Glenn Fredly. Namun dalam hal probabilitas distribusi topik tersebut di seluruh dokumen (prevalensnyai) topik 15 memiliki skor yang cukup rendah. Artinya topik tersebut tidak terlalu sering diberitakan. Hal yang sama juga terjadi pada Topik7, Topik13, Topik18, Topik4, dan Topik11.

Sebaliknya jika dilihat dari nilai prevalensinya, maka terlihat bahwa Topik17 memiliki nilai tertinggi. Artinya, pemberitaan seputar pemberlakuan PSBB di Jakarta dan sekitarnya menjadi topik yang sering muncul dalam pemberitaan. Meskipun setiap kata yang termasuk kedalam Topik17 memiliki tingkat asosiasi antar kata yang sangat rendah.

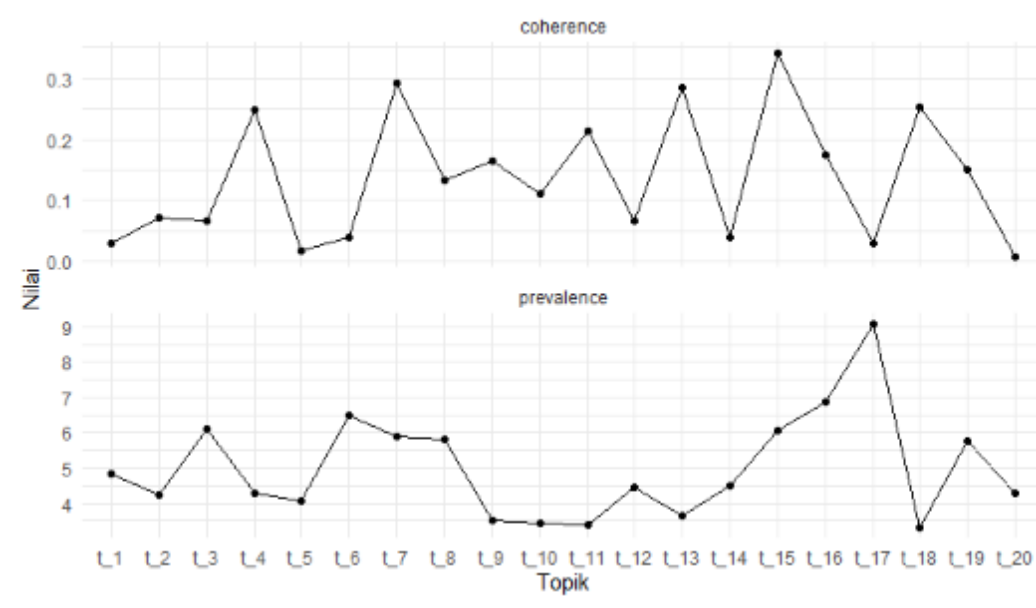

Gambar 5. Nilai Koherensi dan Prevalensi Topik.

Tabel 1. Sepuluh kata tertinggi dalam setiap topik

\begin{tabular}{|lllll|}
\hline Topik1 & Topik2 & Topik3 & Topik4 & Topik5 \\
\hline pemerintah & napi & warga & kartu & mandiri \\
mudik & polisi & sembako & prakerja & mobil \\
jokowi & dpr & terdampak & kartu_prakerja & pekerja \\
Soal & asimilasi & polisi & kerja & karantina \\
covid & anggota & bantuan & harga & malaysia \\
masyarakat & tni & paket & tugas & indonesia \\
larang & narkoba & tewas & ruu & km \\
anggaran & polri & warga_terdampak & gugus & wni \\
presiden & ketua & pria & gugus_tugas & isolasi_mandiri \\
terkait & kembali & korban & cipta & harga \\
\hline Topik6 & Topik7 & Topik8 & Topik9 & Topik10 \\
\hline pemain & medis & covid & masker & Tempat \\
liga & tenaga & positif & kota & Kampong \\
united & apd & pasien & pakai & Karantina \\
barcelona & tenaga_medis & meninggal & wali & Cukai
\end{tabular}




\begin{tabular}{|lllll|} 
persib & covid & positif_covid & wali_kota & Bea \\
inggris & bantu & pdp & warga & pulang \\
madrid & masker & sembuh & pakai_masker & bea_cukai \\
liverpool & bantuan & warga & viral & isolasi \\
kembali & lawan & pasien_positif & pasar & jepang \\
latihan & tangani & satu & zona & pulang_kampung \\
\hline Topik11 & Topik12 & Topik13 & Topik14 & Topik15 \\
\hline Rumah & ramadhan & test & jokowi & Glenn \\
Belajar & rumah & rapid & dampak & Fredly \\
belajar_rumah & puasa & rapid_test & presiden & glenn_fredly \\
Tvri & masjid & rumah & covid & Lagu \\
atlet & tarawih & sakit & penyebaran & kartini \\
wisma & tetap & kabar & cegah & Istri \\
wisma_atlet & jelang & rumah_sakit & pemerintah & ungkap \\
online & ibadah & jalani & ekonomi & Anak \\
Live & mui & gaji & industri & Chord \\
streaming & ramadan & tes & i & Sang \\
\hline Topik16 & Topik17 & Topik18 & Topik19 & Topik20 \\
\hline covid & psbb & ramadhan & covid & Cara \\
pandemi & jakarta & hujan & kasus & Polda \\
virus & kota & bmkg & positif & rumah \\
virus_covid & mudik & wilayah & pasien & zodiak \\
tengah & penumpang & cuaca & update & Kerja \\
pandemi_covid & dki & peringatan & sembuh & Ramalan \\
wabah & pemkot & jadwal & meninggal & ramalan_zodiak \\
tengah_pandemi & bandung & dini & update_covid & Metro \\
wabah_covid & warga & pcr & orang & polda_metro \\
tengah_wabah & aturan & h & indonesia & Tips \\
\hline & & & & \\
\hline
\end{tabular}

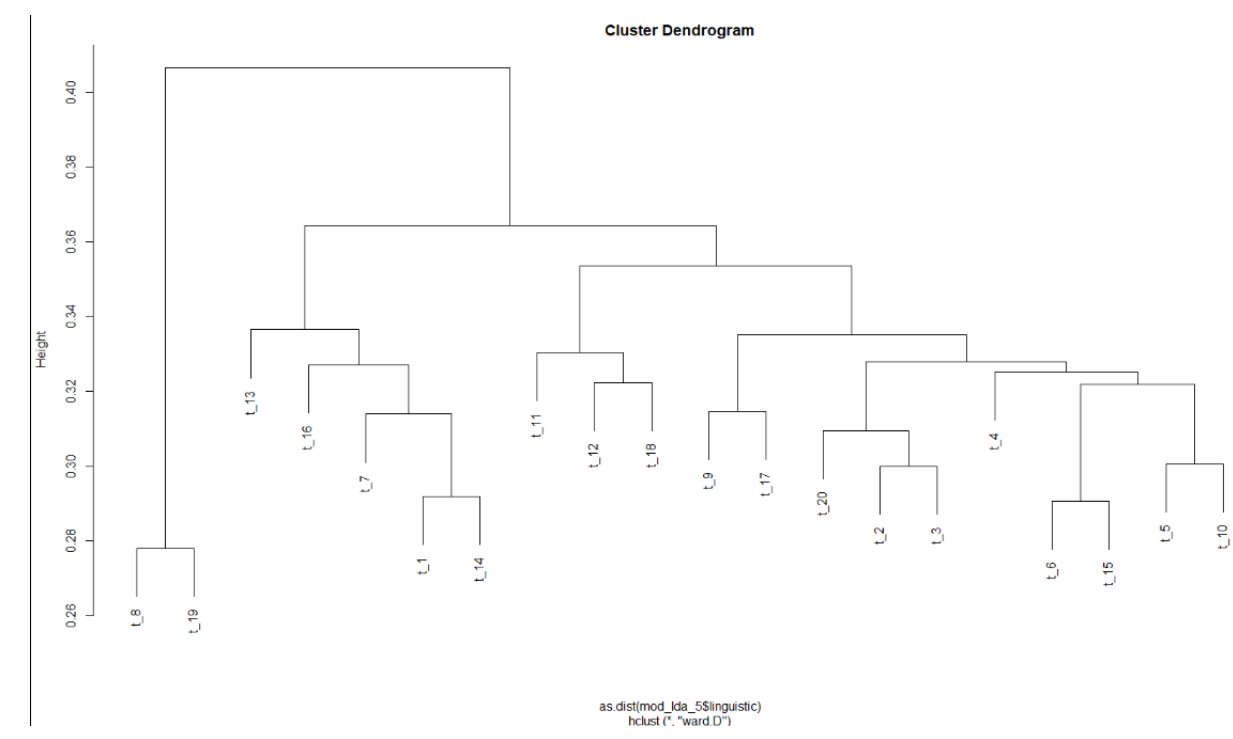

Gambar 6. Pengelompokan Topik Menggunakan Dendrogram.

Gambar 6 menunjukkan pengelompokkan topik-topik tersebut menggunakan Dendrogram. Dendrogram merupakan diagram yang merangkum proses pengelompokkan secara hierarki 
dengan menggunakan jarak Hellinger (jarak antara 2 vektor probabilitas). Dengan dendrogram maka dapat terlihat jelas bagaimana topik-topik tersebut terkait erat. Misalnya, pada Gambar 6 terlihat bahwa ada kesamaan yang lebih besar antara topik 8 dan 19. Selanjutnya bila topik-topik tersebut ingin diringkas menjadi 4 kelompok, maka akan menghasilkan:

- Kelompok 1 : Topik8 dan Topik19

- Kelompok 2 : Topik13, Topik16, Topik7, Topik1, dan Topik14

- Kelompok 3 : Topik11, Topik12 dan Topik18

- Kelompok 4 : Topik9, Topik17, Topik20, Topik2, Topik3, Topik4, Topik6, Topik15, Topik5 dan Topik10

\section{KESIMPULAN}

Pada penelitian ini telah diaplikasikan pemodelan topik menggunakan LDA (Latent Dirichlet Allocation) terhadap pemberitaan oleh 9 portal berita nasional selama masa pemberlakuan PSBB yang pertama. Berdasarkan hasil yang diperoleh maka dapat disimpulkan beberapa hal sebagai berikut:

- Teknik Topik Modeling menggunakan metode LDA sangat berguna untuk mendapatkan informasi dari sekumpulan data teks yang sangat besar yang tidak terstruktur.

- Perlu kehati-hatian dalam menginterpretasikan hasil yang pengelompokkan topik yang diperoleh dengan mempertimbangkan nilai koherensi antar kata (terms) yang ada dalam suatu topik.

- Dalam bentuk visualisasi, kata yang sering muncul dalam pemberitaan selama masa PSBB I sebagaimana diperlihatkan Gambar 1 dan 2. Terilhat bahwa secara umum dari 20 kata yang sering muncul dalam judul pemberitaan selama masa PSBB pertama hampir seluruhnya terkait pandemic Covid-19 serta kebijakan PSBB yang diambil pemerintah.

- Hasil penelitian ini menunjukkan bahwa selama pemberlakuan kebijakan PSBB pemberitaan 9 portal berita online dapat dikelompokkan kedalam 4 kelompok besar pemberitaan: perkembangan kasus Covid-19, penanganan dampak pademi, seputar Ramadhan dan kegiatan belajar di rumah, serta berita lain-lain diantaranya seputar: PSBB, kriminal, hiburan, dan politik.

\section{DAFTAR PUSTAKA}

Alghamdi, R., \& Alfalqi, K. (2015). A Survey of Topic Modeling in Text Mining. International Journal of Advanced Computer Science and Applications. https://doi.org/10.14569/ijacsa.2015.060121

Blei, D. M., Ng, A. Y., \& Jordan, M. I. (2003). LDA-blei.pdf, 3, 993-1022. https://doi.org/10.1162/jmlr.2003.3.4-5.993

Feinerer, I. (2008). Dissertation A Text Mining Framework in R and Its Applications Ingo Feinerer. Statistics, Doktors de(October), 1-189. https://doi.org/10.1373/49.6.994

Feldman, R., \& Sanger, J. (2007). The text mining handbook: advanced approaches in analyzing unstructured data. Cambridge university press.

Griffiths, T. L., \& Steyvers, M. (2004). Finding scientific topics. Proceedings of the National Academy of Sciences of the United States of America, 101(SUPPL. 1), 5228-5235. https://doi.org/10.1073/pnas.0307752101

Han, J., Kamber, M., \& Pei, J. (2012). Data Mining: Concepts and Techniques. Data Mining: Concepts and Techniques. https://doi.org/10.1016/C2009-0-61819-5

Hofmann, T. (2001). Unsupervised learning by probabilistic Latent Semantic Analysis. Machine Learning, 42(1-2), 177-196. https://doi.org/10.1023/A:1007617005950

Jelodar, H., Wang, Y., Yuan, C., Feng, X., Jiang, X., Li, Y., \& Zhao, L. (2019). Latent Dirichlet allocation (LDA) and topic modeling: models, applications, a survey. Multimedia Tools and Applications (Vol. 78). https://doi.org/10.1007/s11042-018-6894-4

Mimno, D., Wallach, H. M., Talley, E., Leenders, M., \& McCallum, A. (2011). Optimizing semantic coherence in topic models. EMNLP 2011 - Conference on Empirical Methods in Natural Language Processing, Proceedings of the Conference, (2), 262-272.

Nurkinan. (2017). Dampak Media Online Terhadap Perkembangan Media Konvensional. Jurnal Politikom Indonesiana, 2(2), 28-42. Retrieved from https://journal.unsika.ac.id/index.php/politikomindonesiana/article/download/962/792 
Porteous, I., Newman, D., Ihler, A., Asuncion, A., Smyth, P., \& Welling, M. (2008). Fast collapsed gibbs sampling for latent dirichlet allocation. Proceedings of the ACM SIGKDD International Conference on Knowledge Discovery and Data Mining, (May), 569-577. https://doi.org/10.1145/1401890.1401960

Stevens, K., Kegelmeyer, P., Andrzejewski, D., \& Buttler, D. (2012). Exploring topic coherence over many models and many topics. EMNLP-CoNLL 2012 - 2012 Joint Conference on Empirical Methods in Natural Language Processing and Computational Natural Language Learning, Proceedings of the Conference, (July), 952-961.

Stolee, J. (2016). An Evaluation of Topic Modelling Techniques for Twitter, 1-11.

\section{\{Bibliography}

